\title{
Interactive comment on "What can we learn about urban air quality with regard to the first outbreak of the COVID-19 pandemic? A case study from Central Europe" by Imre Salma et al.
}

Imre Salma et al.

salma@chem.elte.hu

Received and published: 8 December 2020

The comment was uploaded in the form of a supplement:

https://acp.copernicus.org/preprints/acp-2020-997/acp-2020-997-AC1-supplement.pdf

Interactive comment on Atmos. Chem. Phys. Discuss., https://doi.org/10.5194/acp-2020-997, 2020. 